7. Reprod. Fert. (1968) 16, 55-58

\title{
ENDOCRINE STUDIES AT HIGH ALTITUDE
}

\author{
IV. CHANGES IN THE SEMEN OF MEN
}

\author{
J. DONAYRE, R. GUERRA-GARGÍA, F. MONCLOA \\ AND L. A. SOBREVILLA \\ Instituto de Investigaciones de la Altura, Departmento de Endocrinología, \\ Universidad Peruana Cayetano Heredia, Apartado 6083, Lima, Perú
}

(Received 9th May 1967, revised 10th October 1967)

\begin{abstract}
Summary. Nine men were exposed to an altitude of $14,000 \mathrm{ft}$ for 4 weeks. Sperm counts showed persistent decrease, indicating damage early in the spermatogenic cycle. A significant increase of abnormal forms, mainly of the 'mature' type, was observed, revealing that damage also occurs at a late stage of spermateliosis. Motility declined without changes in live spermatozoa. Motility changes and fructose elevation seem to be unrelated and due to separate effects of hypoxia. Seminal $\mathrm{pH}$ and fructose were raised; citric acid remained within normal limits until descent to sea level. Descent usually led to recovery.
\end{abstract}

\section{INTRODUCTION}

Brief exposure to high altitude has been reported to cause intense testicular lesions in animals (Monge, San Martín, Atkins \& Castañon, 1945; GuerraGarcía, 1959). Impairment of spermatogenesis, destruction of germinal epithelium, and syncytial replacement of the tubular structure with ensuing testicular atrophy have been observed. Prompt return to normal occurs with descent to sea level. However, the duration of these changes is not precisely known, nor is it known whether adaptation takes place. Simulated altitude in low-pressure chambers provokes similar alterations (Gordon, Tornetta \& Charipper, 1943; Shettles, 1947). The histological damage in some species has been correlated with alterations of number and quality of spermatozoa: sperm concentration declines in sheep transported to high altitude, sometimes to azoospermia; in addition, motility declines, $\mathrm{pH}$ rises and also the number of abnormal forms increases (Monge et al., 1945; San Martín, Atkins \& Castañon, 1945; San Martín, 1950). Slowing of sperm transport in rabbits has been reported (San Martín, 1950). However, Moore \& Price (1948) did not find major changes in testicular weight and reproductive performance under somewhat different experimental conditions. Since no information on human beings is available, we describe below the semen characteristics of nine men exposed to high altitude. 


\section{MATERIAL AND METHODS}

Nine Peruvian volunteers, of coastal origin and residence, aged from 18 to 22 years, were taken to Cerro de Pasco (14,000 ft) for 4 weeks. Living conditions were similar to those at sea level; adequate heated quarters were provided. Previous physical examinations did not reveal any abnormality in the reproductive and endocrine systems. Each subject collected a total of ten semen samples by masturbation, the first five weekly at sea level before ascent (controls). Samples were taken on the 7th, 14th and 27th days of the stay at Cerro de Pasco, and two final samples on the 8th and 15th days after return to sea level. Sperm counts were made by haemocytometer and are reported as total number of cells. Motility is expressed as percentage of all cells showing movement. Percentage of live spermatozoa was obtained by staining with eosin-nigrosin; haematoxylin and eosin were used for counting abnormal forms. Fructose was analysed by Cole's modification of Roe's method (Bacon \& Bell, 1948) and citric acid by the procedure of Saffran \& Denstedt (1948) in seminal plasma after precipitation with $10 \%$ trichloroacetic acid. The $\mathrm{pH}$ of fresh semen was also recorded.

In the account that follows, each mean is followed by its standard error.

\section{RESULTS}

The results are summarized in Text-fig. 1. Mean sperm count at sea level before ascent was $7 \cdot 42 \times 10^{8} \pm 67 \cdot 7$. A statistically significant and continuous decrease in sperm count was observed throughout the 42 days of the experiment. The control percentage of motile cells was $85 \cdot 8 \pm 1 \cdot 0$. A consistent decrease below this level occurred during the stay at high altitude. Return to sea level markedly improved motility. No corresponding alteration in percentage of live cells was detected. A marked and sustained increase in abnormal forms was observed at high altitude. This continued after return to sea level. The abnormal types were classified by the system of MacLeod (1964). At the 7th and 14th days of exposure, changes in the neck and middle piece, with persistence of the cytoplasmic droplet, were commoner than tapering forms; the latter were second in frequency. On the 27th day of exposure there were mainly alterations in the structure of the head, with increasing numbers of immature cells.

The $\mathrm{pH}$ value for the period before ascent was $7 \cdot 59 \pm 0 \cdot 03$. After 1 week at high altitude there was a tendency towards greater alkalinity. The highest values were on the 14 th day of exposure $(8 \cdot 23 \pm 0.04)$. A clear tendency to recovery appeared at the 27 th day and normality was restored after descent.

From a value of $165.5 \mathrm{mg} / 100 \mathrm{ml} \pm 29.05$, fructose levels rose during the first 2 weeks of the experimental period. At the 27 th day fructose had returned to normal. Changes in citric acid content were of doubtful significance.

\section{DISCUSSION}

The structural and metabolic effects of high altitude both appear rather early: there were always changes in most of the variables studied at the end of the first week. 
The persistently low sperm counts suggest gradual damage at an early stage of the cycle of spermatogenesis described by Clermont (1963). Further evidence on this question might be obtained by using longer exposure times, since the duration of spermatogenesis in man is about 74 days (Heller \& Clermont, 1964), or by histological studies to identify the precise location of the damage.

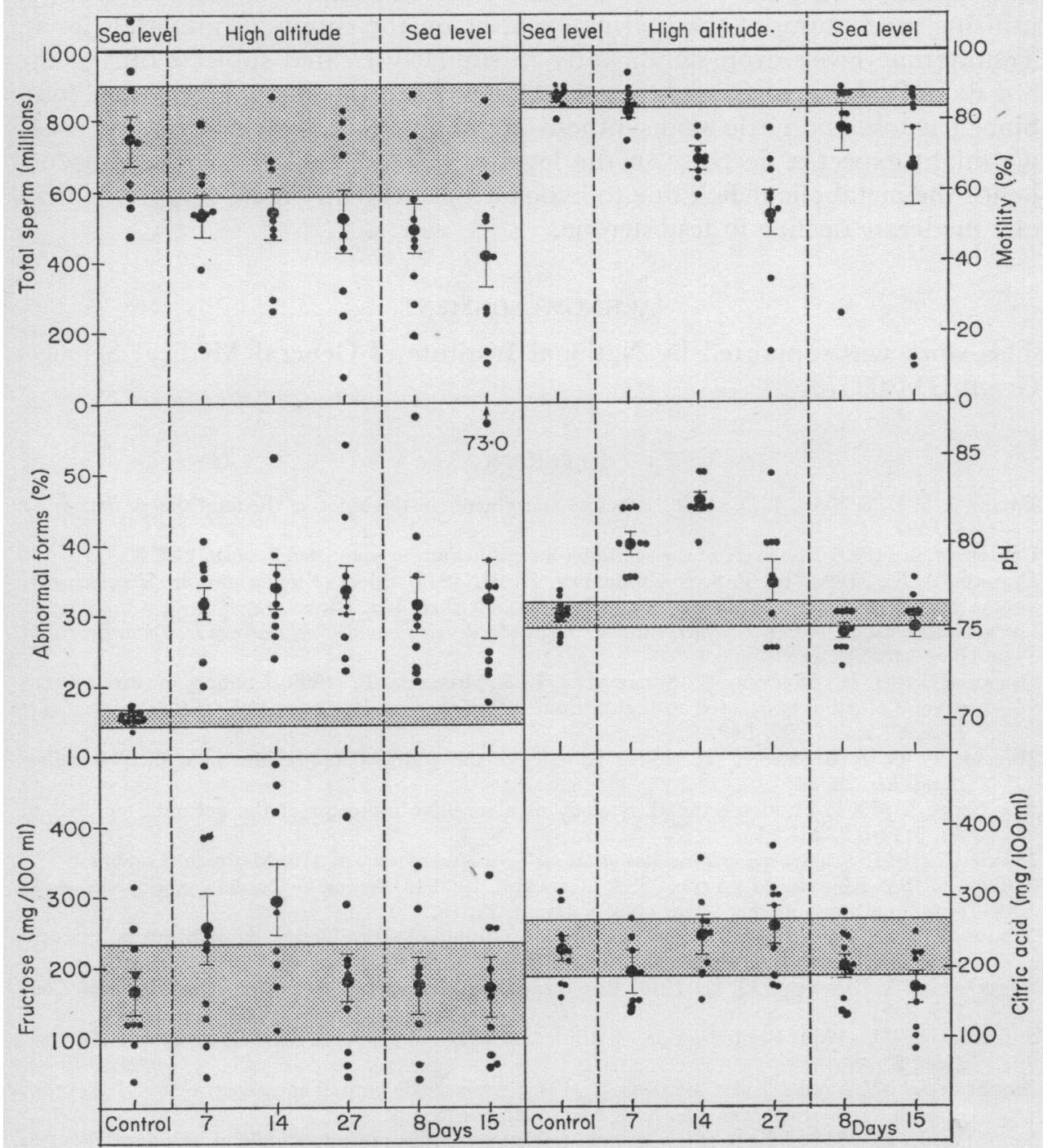

TExT-FIG. 1. Characteristics of semen during exposure to high altitude. Each mean (large circle) is accompanied by a vertical bar which represents its standard error. The shaded area in each case represents the $95 \%$ confidence limits of the control mean.

The prompt increase in abnormal forms, to $33 \%$ on the 14th day of exposure, and the 'mature' character of the predominant type of abnormality, both point to damage at a late stage of spermateliosis. This also conforms with the rapid return to structural normality on descent. The presence of abnormal forms as 
early as the 7 th day suggests either injury to epididymal spermatoza or accelerated migration.

Changes in motility did not parallel the incidence of abnormal forms. Similarly there was no clear relationship between decreased motility and increase in fructose. The loss of motility without change in the percentage of live spermatozoa could have been due to a noxious effect on the energyutilizing mechanism of the spermatozoa, or on the supply of materials for it. Testosterone levels drop significantly in similarly treated subjects during the 3rd day of exposure (Guerra-García, Donayre, Sobrevilla \& Moncloa, 1965). Since fructose and citric acid synthesis are androgen-dependent (Mann, 1964) we might expect a decrease in the level of fructose, but this did not occur; hence the metabolic deficit due to hypoxia was evidently more important than any moderate decline in testosterone.

\section{ACKNOWLEDGMENT}

This work was supported by National Institute of General Medical Sciences Grant GM 08576.

\section{REFERENCES}

Bacon, J. S. D. \& Bell, J. D. (1948) Fructose and glucose in the blood of the fetal sheep. Biochem. F. $42,397$.

Clermont, I. (1963) The cycle of the seminiferous epithelium in man. Am. F. Anat. 112, 35.

Gordon, A. S., Tornetta, F. S. \& Charipper, H. A. (1943) Effect of low atmospheric pressure on reproductive system of the male rat. Proc. Soc. exp. Biol. Med. 53, 6.

Guerra-García, R. (1959) Hipofisis, adrenales y testiculos de cobayos a nivel del mar y en la altura. Br. thesis, Fac. Med. Lima.

Guerra-García, R., Donayre, J., Sobrevilla, L. \& Moncloa, F. (1965) Changes in urinary testosterone of subjects exposed to high altitude. Excerpta med. int. Congr. Series. VIth Pan Am. Congr. Endocr. (Mexico), 99, E62.

Heller, G. G. \& Clermont, Y. (1964) Kinetics of the germinal epithelium in man. Recent Prog. Horm. Res. 20, 545.

MACLEOD, J. (1964) Human seminal cytology as a sensitive indicator of the germinal epithelium. Int. J. Fert. 9, 281.

MANN, T. (1964) Biochemistry of semen and of the male reproductive tract, p. 316. Methuen, London.

Monge, C., San Martín, M., Atkins, J. \& Castañon, J. (1945) Aclimatación del ganado ovino en las grandes alturas. An. Fac. Med. Univ. S Marcos, $28,15$.

MoOre, C. R. \& PRICE, D. (1948) A study at high altitude of reproduction, growth, sexual maturity and organ weights. F. exp. Zool. 108, 171.

Saffran, M. \& Denstedt, O. F. (1948) Rapid method for determination of citric acid. F. biol. Chem. $175,849$.

SAN Martín, M. (1950) Reproducción y fertilidad en las grandes alturas. Revta Fac. Med. vet. Univ. nac., Lima, 5, 140.

San Martín, M., Atrins, J. \& Castañon, J. (1945) Aspectos de la fisiología experimental de la reproducción en la altura. An. Fac. Med. Univ. S Marcos, 28, 32.

Shettles, L. B. (1947) Effects of low oxygen tension on fertility in adult male guinea pigs. Fedn Proc. Fedn Am. Socs exp. Biol. 6, 200. 